\title{
Efficacy of financial measures of marketing: It depends on markets and marketing strategies
}

\author{
RECEIVED: I5 MARCH, 200 I \\ Jagdish N. Sheth and Arun Sharma* \\ *Department of Marketing, University of Miami, PO Box 248/47, Coral Gables, \\ Fl 33/24. Tel: (305) 284 1770; Fax: (305) 284 5326; e-mail: asharma@miami.edu
}

Jagdish N. Sheth

is Charles $\mathrm{H}$.

Kellstadt Professor

of Marketing at

the Goizueta

Business School at

Emory University

and Arun Sharma

is Professor of

Marketing at the

University of

Miami.

\section{ABSTRACT}

There has been an increase in attention given to the financial returns of the marketing function, primarily because marketing costs are seen as increasing, with declining returns. For example, both brand loyalty and customer satisfaction levels are declining in spite of increasing marketing expenditures. One of the reasons for the increased pressure on marketing is that the marketing function has utilised limited financial measures of efficiency and effectiveness. This paper examines previous research in this area, and provides a framework from which to examine existing financial measures of marketing evaluation that will lead to future research in this area.

\section{INTRODUCTION}

The financial evaluation of marketing strategies is of increasing interest to both academics and practitioners. There are two major reasons for the enhanced interest. First, dotcom firms have been criticised for their marketing and advertising excesses, in which the financial returns on marketing expenditures were not evaluated. For example, Pets.com spent $\$ 27 \mathrm{~m}$ on advertising (including Super Bowl advertisements) as their customer acquisition costs soared to more than $\$ 500$ per customer. The result is that Pets.com no longer exists. Secondly, in the search for internal efficiencies and process re-engineering of organisations, primary departments such as manufacturing and corporate support have already been examined. As an example, manufacturing and operations costs have declined from 50 per cent of corporate costs in the 1950s to 30 per cent or less today. ${ }^{1}$ In contrast, marketing costs today make up to 50 per cent or more of corporate costs, a dramatic increase from 20 per cent in the 1940s. As a result, senior executives are now looking at the financial efficiency and effectiveness of a firm's marketing expenditures.

In addition, recent research challenges some of the assumptions that marketers have long held regarding the 
financial impact of marketing actions. For example, Reinartz and Kumar demonstrate that the marketing axiom that longer customer relationships lead to better financial results may not hold true. $^{2}$ The lack of understanding of the financial implications of marketing has led senior executives to question the financial productivity of marketing. Webster interviewed the chief executive officers (CEOs) of 30 major corporations to determine their views of the marketing function. These CEOs felt that the marketing function had a poor understanding of the financial implications of marketing actions:

'the major issue is one of marketing productivity. Marketing needs a better method of making cost/benefit analysis on marketing expenditures — to make good, intelligent choices on how to get the most out of our marketing dollars, including marketing support, not just research on new products, media, etcetera. The concern is that while costs are rising, marketing is not finding new ways to improve marketing efficiency' ${ }^{3}$

The purpose of this paper is to examine issues associated with the financial evaluation of the marketing function. The marketing function may be ignoring the heightened sensitivity of firms toward marketing expenditures. It may be similar to Webster's examination of the changing role of marketing, in which he suggests a similarity between the Peruvian Indians who thought the sails of Spanish invaders were weather phenomena and did not prepare for attack, and marketers who might be ignoring important information from their environment (including financial accountability) because it is deviant from past experience. ${ }^{4}$

Another aim of the paper is to clarify that thought-provoking work has been conducted in the marketing area. Srivastava, Shervani, and Fahey have suggested that some of marketing's accountability problems may be due to the lack of measures that can be used to evaluate marketing activities. They suggest that assetbased evaluation be performed in ways that include measures such as net present value, discounted cash flows, and shareholder value creation. ${ }^{5}$ Such measures are forward looking, in that they capture the current value of anticipated future cash flows. They suggest that traditional measures such as sales and market share are backward looking, reflecting events that have already occurred.

In the next section, the literature on the financial evaluation of marketing is examined. Then a framework is provided to examine measures based on the market and industry. The final section summarises the research.

\section{LITERATURE REVIEW}

There has been extensive work on the financial measurement of marketing activities. In this section, the literature is examined. 


\section{Difficulty in measuring marketing returns}

Marketing outputs are inherently regarded as more difficult to measure. Whereas manufacturing and accounting systems developed together, increased expenditures associated with marketing are a more recent phenomenon. In the beginning of the last century and through the advent of mass manufacturing, manufacturing costs were the major components of the cost of doing business. Therefore, there was an emphasis on accurately measuring and improving manufacturing efficiency. Such attention has not been lavished on marketing costs. Foster and Gupta discuss some of the more important factors that have led to the lack of attention to financial measures of marketing.

First, traditional marketing literature emphasises sales volume, sales revenue and market share. Cost management and management accounting research focuses on cost of goods. There has been little intersection or combination of these research areas.

Secondly, manufacturing costs have been accurately calculated by the accounting function. This expertise has not translated well, however, for the marketing function. Foster and Gupta discuss two reasons:

- manufacturing costs are committed to infrastructure (plants and machinery) or product design. In contrast, marketing costs are discretionary, even just prior to expenditure
- there is greater flexibility in altering marketing expenditures in the relatively short term, whereas manufacturing cost changes need a longer-term horizon.

Thirdly, determining the effectiveness and efficiency of marketing functions remains a challenge. For example, there may be a considerable lag between advertising expenses and market returns that leads to difficulty in performing causal analysis.

Fourthly, most marketing assets are intangible (eg brands and customer loyalty). Although significant resources are deployed to maintain these resources, traditional financial measures do not capture these values. ${ }^{6}$

\section{Focus on inputs}

The majority of research on financial evaluation of marketing is performed on the input (spending) rather than the output (outcome). As discussed in the previous section, marketing outcomes and outputs are harder to measure. Marketing research continues to emphasise inputs. For example, in an article examining customer equity, Blattberg and Deighton develop a model for determining the expenditures firms need to make on acquisition when compared to retention. Although the model is based on customers' equity (outputs), the emphasis of the research is on expenditures (inputs). ${ }^{7}$

Another reason that inputs are examined is that they stand out in balance sheets. For example, Foster and 
Gupta calculated selling, general and administrative costs (SG\&A) as a percentage of sales for industrial classifications. ${ }^{8}$ Typically, marketing expenditures are listed in SG\&A. For 1991, they determined that ten industries had SG\&A expenses over 40 per cent of sales revenue. The highest expenses were for the perfume, cosmetics and toilet preparation category that had an SG\&A-to-sales ratio of 53.2 per cent. Interestingly, the data suggest that for the perfume, cosmetics and toilet preparation category the SG\&A expenses are higher than the cost of goods and profits combined. Because outputs have been hard to measure, and marketing expenditures are becoming larger and more apparent, the focus on inputs is expected to increase.

\section{Evaluation of marketing outputs}

The concern of firms regarding financial outcomes has led to increased research in the area of determining the relationship between marketing constructs and financial outcomes. One of the primary research areas addressing the financial outcomes of marketing outputs is the relationship between market share and profitability. In spite of extensive interest in this area and substantial research, an understanding of the exact relationship remains elusive. Some of the prominent research in this area is also directed to customer satisfaction, long-term relationships, and retail productivity.

\section{Customer satisfaction}

Because of marketing's concern with customer satisfaction, the relationship between customer satisfaction and financial performance has been examined by a large number of researchers in the last decade. The research is unanimous in suggesting a positive relationship between satisfaction and profitability. ${ }^{9}$ Using the construct of 'customer delight' the study of Keiningham et al. demonstrates that customer delight continues to lead to better financial results. ${ }^{10}$ The majority of data, however, remains at the aggregate level and has not been translated into firm-level measures.

\section{Long-term relationships}

The financial evaluation of longterm relationships is an area that has provided surprising results. Reinartz and Kumar found that for a mail order firm the financial returns of longterm customers were not dramatically higher than that of customers who only bought once or twice. ${ }^{11}$ In addition, studies by Moorman, Zaltman and Desphande ${ }^{12}$ and by Grayson and Ambler, ${ }^{13}$ demonstrate that the length of relationship may have a negative relationship on financial returns. Therefore, marketing investment in long-term relationships may not provide the financial returns that anecdotal feedback may suggest.

\section{Retail productivity}

Financial productivity of retailing has been extensively examined by both practitioners and researchers. ${ }^{14-19}$ 
The earlier research in retailing predominantly examined non-financial retailing output measures such as sales per square foot or sales per employee. ${ }^{20}$

More recently, Kamakura, Lenartowicz, and Ratchford, ${ }^{21}$ and Donthu and $\mathrm{YoO}^{22}$ identified a number of problems with traditional non-financial measures. First, most retailing situations have financial outputs that are not addressed in traditional analysis. ${ }^{23}$ Secondly, most measures are sales management oriented (eg sales per hour) rather than functioning as measures of the total retail situation. ${ }^{24}$ Thirdly, output is defined as a supply-side concept. The market and financial conditions are normally not included in the analysis. ${ }^{25,26}$ Fourthly, research that has used standard regression analysis used average store performance rather than the best performers. ${ }^{27,28}$ Finally, very few studies have examined the context of the efficiency of different outlets of a firm. ${ }^{29,30}$ Recent research, however, has been concentrating on the financial measures of retailing with the inclusion of the strategic and financial profit model in standard retailing practices and in textbooks on retailing. ${ }^{31}$

\section{Summary}

The literature reviewed in the previous section suggests that, traditionally, financial measures have not been used extensively or in a consistent manner in either academics or in practice. New research has, however, begun to examine these measures in depth. In the next section, some of the recent research that has examined the financial measures of marketing is discussed.

\section{FINANCIAL MEASURES OF THE FIRM BASED ON MARKETING}

In one of the earlier studies that examined the effect of marketing expenditures on financial markets, Simon and Sullivan suggest that financial markets evaluate marketing expenditures positively in terms of equity and debt rating. They also suggest that industries and firms with 'big brand names' have higher market evaluations. Some effects of marketing expenditures on financial markets at the firm level were also observed. ${ }^{32}$

Foster and Gupta ${ }^{33}$ and Ittner and Larcker $^{34}$ have suggested that firms should use accounting measures such as activity based accounting and should use evaluation methods such as economic value added (EVA) measures for evaluating marketing activities. The exact process of implementing the financial measures has not been clarified.

Srivastava, Shervani, and Fahey suggest a better link between market-based assets created through marketing and shareholder value. ${ }^{35}$ They propose that marketing creates market-based assets such as customer relationships that include brands and installed base, and partner relationships that include channels, co-branding and networks. These marketbased assets are translated into market performance on multiple 
dimensions - faster market penetration (faster trials, referrals, adoption), price premium, share premium, extensions, sales/service costs and loyalty/retention. Better market performance of firms leads to enhanced shareholder value through accelerated cash flows, enhanced cash flows, reduction in volatility and vulnerability of cash flows, and enhancement of the residual value of cash flows. Although the links between marketing are conceptually strong, the measurement issues need to be resolved.

\section{SHETH AND SHARMA'S FRAMEWORK}

The authors have developed a framework to better understand the issues of financial measurement of marketing activities (Table 1). The three headings show the type of market in which the firm operates service, product and knowledge-based. The left-hand column shows the type of marketing practised by the firm product/brandcentric, segmentcentric and customercentric.

\section{Output-based markets}

Markets can be divided into three major output categories - services, products and knowledge-based. Although a market can encompass more than one category, the discussion is limited to discrete markets. The product service dichotomy is well understood. Products have tangible features and can be stored, whereas services are intangible and perish- able. Knowledge-based industries are found when there are high up-front costs and when firms emphasise the development, application, and diffusion of new knowledge. ${ }^{36}$ Software, semiconductor and telecommunication industries are examples of knowledge industries. The basis of marketing exchange - the context of demand ambiguity - that leads to pricing strategies and cost structures that determine profitability is discussed. The conclusions are presented in Table 2.

\section{Exchange basis and demand ambiguity}

Service industries are very sensitive to alternatives. The primary reason is that customers and businesses can insource when they feel that the prices are too high. For example, car washes are outsourced in times of prosperity, and insourced in times of scarcity. Service industries have the highest level of demand ambiguity. In product markets, firms can extend the life of present products to a certain time limit. Therefore, demand ambiguity is at a medium level. In knowledge markets, firms do not have a rational alternative because of the high costs, and therefore have the least amount of ambiguity.

\section{Pricing}

Service industries have high variable costs, and pricing strategies are oriented toward variable costs and demand interaction. Prices are high when either demand is high (with low levels of possible insourcing) or when 
Table 1

CHARACTERISTICS OF MARKETS, MARKETING AND FINANCIAL MEASURES

\begin{tabular}{|c|c|c|c|}
\hline & Service markets & Product markets & Knowledge markets \\
\hline $\begin{array}{l}\text { Customercentric } \\
\text { marketing }\end{array}$ & $\begin{array}{l}\text { Customer level } \\
\text { marketing: precise } \\
\text { costing and } \\
\text { negotiated pricing; } \\
\text { based on individual } \\
\text { customer-based } \\
\text { activity-based } \\
\text { accounting }\end{array}$ & $\begin{array}{l}\text { Demand-driven } \\
\text { manufacturing: } \\
\text { precise costing and } \\
\text { negotiated pricing; } \\
\text { based on production } \\
\text { costs by modular } \\
\text { assembly }\end{array}$ & $\begin{array}{l}\text { Consulting services: } \\
\text { imprecise costing } \\
\text { and negotiated } \\
\text { pricing; based on } \\
\text { perceived benefits }\end{array}$ \\
\hline $\begin{array}{l}\text { Segmentcentric } \\
\text { marketing }\end{array}$ & $\begin{array}{l}\text { Multiple service } \\
\text { level service: } \\
\text { imprecise costs and } \\
\text { prices; based on } \\
\text { potential size of } \\
\text { market and benefits }\end{array}$ & $\begin{array}{l}\text { Segmentation of } \\
\text { markets: imprecise } \\
\text { costs and prices; } \\
\text { based on volume } \\
\text { and benefits }\end{array}$ & $\begin{array}{l}\text { Specialised software } \\
\text { sales: imprecise } \\
\text { costing based on } \\
\text { distribution of costs } \\
\text { over anticipated } \\
\text { number of units }\end{array}$ \\
\hline $\begin{array}{l}\text { Product/brand- } \\
\text { centric marketing }\end{array}$ & $\begin{array}{l}\text { Service contracts: } \\
\text { precise costing and } \\
\text { pricing; based on } \\
\text { failure rates and } \\
\text { service costs }\end{array}$ & $\begin{array}{l}\text { Product sales: } \\
\text { precise costing and } \\
\text { pricing; based on } \\
\text { volume }\end{array}$ & $\begin{array}{l}\text { Chip sales: less } \\
\text { precise costing and } \\
\text { pricing; based on } \\
\text { distribution of costs } \\
\text { over anticipated } \\
\text { number of units }\end{array}$ \\
\hline
\end{tabular}

competitive intensity is low. Prices are close to variable costs when demand is low (with high levels of possible insourcing) or when competitive intensity is high. In product markets, pricing is typically costplus, with volume discounts provided based on scale economies. Knowledge markets have the most difficulty pric- ing products because fixed costs are high and marginal costs are close to zero. Firms determine the anticipated benefits of their knowledge base with respect to competition, and attempt to price close to the market. Pricing is also dependent on the supply demand interaction and the size of the market. 
Table 2

\section{CHARACTERISTICS OF MARKETS}

\begin{tabular}{|c|c|c|c|}
\hline & Service markets & Product markets & Knowledge markets \\
\hline Exchange basis & $\begin{array}{l}\text { Sensitive to internal } \\
\text { alternatives }\end{array}$ & Transaction & $\begin{array}{l}\text { No rational internal } \\
\text { alternative }\end{array}$ \\
\hline Demand ambiguity & $\begin{array}{l}\text { High due to } \\
\text { insourcing/ } \\
\text { outsourcing }\end{array}$ & $\begin{array}{l}\text { Medium due to } \\
\text { repair/extended use }\end{array}$ & Low \\
\hline Pricing & $\begin{array}{l}\text { Variable cost and } \\
\text { demand interaction }\end{array}$ & Cost plus & $\begin{array}{l}\text { Fixed cost and } \\
\text { demand interaction; } \\
\text { marginal costs close } \\
\text { to zero }\end{array}$ \\
\hline Cost structures & $\begin{array}{l}\text { High variable } \\
\text { costs/low fixed } \\
\text { costs }\end{array}$ & Mixed & $\begin{array}{l}\text { High fixed } \\
\text { costs/low variable } \\
\text { costs }\end{array}$ \\
\hline
\end{tabular}

\section{Cost structures}

There are significant differences between service and knowledge markets. Typically, labour costs form a large part of service industry costs. These costs are predominantly variable with few fixed costs. In contrast, knowledge industries have very high fixed costs with few variable costs. Product-based industries have both variable and fixed costs.

\section{Type of marketing practised by firm}

The marketing function has undergone dramatic shifts in the last 50 years. ${ }^{37}$ Mass marketing came into vogue after the Second World War when firms began to have better access to mass production technology, better transportation and communication facilities, greater financial resources, and more sophisticated human resources management. Customers had many unmet needs and were satisfied with standardised products at reasonable prices. Competition intensified as regional and local marketers become fully integrated into a unified mass market system. The emphasis of mass market systems is on products, leading companies to adopt organisational forms centred on products.

As competition increased, the resulting increase in product variety rendered mass-market techniques less 
Table 3

\section{CHARACTERISTICS OF MARKETING STRATEGIES}

\begin{tabular}{|c|c|c|c|}
\hline & $\begin{array}{l}\text { Product/brand- } \\
\text { centric marketing }\end{array}$ & $\begin{array}{l}\text { Segmentcentric } \\
\text { marketing }\end{array}$ & $\begin{array}{l}\text { Customercentric } \\
\text { marketing }\end{array}$ \\
\hline Exchange basis & Transactional & $\begin{array}{l}\text { Mixed (transactional } \\
\text { and relational) }\end{array}$ & Relational \\
\hline $\begin{array}{l}\text { Marketing and } \\
\text { financial philosophy }\end{array}$ & Marketing as cost & $\begin{array}{l}\text { Marketing as } \\
\text { differentiator }\end{array}$ & Marketing as assets \\
\hline Pricing strategy & $\begin{array}{l}\text { Pricing based on } \\
\text { volume (costs) }\end{array}$ & $\begin{array}{l}\text { Pricing variations } \\
\text { due to segments }\end{array}$ & Negotiated pricing \\
\hline $\begin{array}{l}\text { Cost allocation to } \\
\text { customers }\end{array}$ & $\begin{array}{l}\text { Imprecise costing } \\
\text { (volume-based } \\
\text { proportional } \\
\text { allocation) }\end{array}$ & $\begin{array}{l}\text { Less precise costing } \\
\text { (volume-based } \\
\text { proportional } \\
\text { allocation) }\end{array}$ & Precise costing \\
\hline
\end{tabular}

effective. ${ }^{38}$ This shift in the marketing discipline occurred primarily in the 1950s when the marketing concept was first recognised, popularised by Kotler, $^{39}$ and widely adopted. As a result, firms started paying more attention to 'markets,' and marketers adopted segmentation. The shift from a 'product orientation' to the marketing concept led to many changes in marketing thought and practice. In the organisational context, marketing thought leaders developed the concept of 'market orientation'. ${ }^{40,41}$ In practice, firms organised around markets and segments, ie created segment-based marketing.

Sheth, Sisodia and Sharma propose that the confluence of demographic and technological factors, as well as dissatisfaction with existing marketing productivity, will lead to the widespread adoption of customercentric marketing. ${ }^{42}$ Customercentric marketing emphasises understanding and satisfying the needs, wants, and resources of individual consumers and customers, rather than those of mass markets or market segments.

The exchange basis, marketing and financial philosophy, pricing strategy and cost allocations of these marketing strategies are discussed and the conclusions presented in Table 3 .

\section{Exchange basis, marketing and financial} philosophy

An interesting aspect of the 'type of marketing practised' by firms is that the exchange basis differs, and executives at 
firms conceptualise marketing expenditures differently. Product/brand marketing philosophy is predominantly transactional, and marketers see marketing expenditures as costs, and predominantly, as costs of a short-term discretionary nature. Therefore, most marketers have included marketing costs in their SG\&A. Segmentcentric marketing philosophy is a mixture of transactions and relationships and marketers increasingly regard the marketing function to be the 'differentiator'. These marketers regard marketing both as a short-term and a long-term investment. In these areas, firms have been using financial methodologies such as EVA that regard advertising as an investment. Customercentric marketing philosophy is predominantly relational, and executives regard marketing as responsible for creating market-based assets such as customer relationships, channels, cobranding and networks. ${ }^{43}$ These market-based assets are translated into enhanced shareholder value, and are typically below the line in knowledge industries.

\section{Pricing strategy}

Pricing strategy follows costing. Customercentric marketers have an accurate measure of individual customer costs and profitability, and this profitability varies from customer to customer. Therefore, since costs vary across individual customers, prices will vary leading to negotiated pricing. Segmentcentric marketers vary, prices based on segment size and on perceived benefits. For product/brandcentric marketers, since the cost-volume relationship is known, pricing also tends to follow a volume relationship.

\section{Cost allocation to customers}

Cost allocation to specific customers is becoming more critical as firms seek the more profitable customers. Sheth, Sisodia and Sharma discuss some of the issues associated with the lack of customer allocation of costs. ${ }^{44}$ For products/brandcentric marketers, costs are typically allocated proportionally to the amount of purchases, ie largervolume customers get a larger proportion of the costs irrespective of usage. Clearly, this method is imprecise because low-volume customers may be consuming a larger proportion of the marketing firm's resources. Segmentcentric marketers have improved costing as expenses as allocated to segments that increases the accuracy of costing. Customercentric marketers, with their focus on individual customers and access to data on individual customers, typically have the most accurate data on firm's expenses on individual customers.

\section{Characteristics of market, marketing and financial measures}

In this section the intersection of markets and marketing, and the financial aspects of costing and pricing issues, associated with each cell are examined. Within each cell an attempt is also made to discern whether an accurate financial evaluation of 
marketing strategies can be undertaken. The conclusions are presented in Table 1.

\section{Product/brandcentric strategies in service markets}

An example of this combination is a service contract. In this situation, thorough historical data costs are typically known, and pricing is typically cost-plus. In some areas there may be cross-subsidisation. The marketing function can be accurately evaluated in pure financial terms of price premiums, and in asset-based financial terms of number of customers and customer loyalty.

\section{Product/brandcentric strategies in product markets}

An example of this combination is a product market such as steel. In this situation, thorough historical data costs are typically known. Pricing is typically cost-plus based on volume manufactured and purchased. In some areas there may be cross-subsidisation. In this area, the marketing function can also be accurately evaluated in pure financial terms of price premiums, and in asset-based financial terms of number of customers and customer loyalty.

\section{Product/brandcentric strategies in knowledge markets}

Examples of this combination are knowledge industries such as telecommunication equipment and semiconductors. In these situations, costs are known and typically dependent on volume, with increased volume dramatically reducing total per unit costs. Pricing is difficult because demand projections need to be made. Market prices based on supply and demand typically prevail. Because of the similarity of knowledge outputs in the market space, however, the marketing function can be accurately evaluated in pure financial terms of price premiums, and in asset-based financial terms of number of customers and customer loyalty.

\section{Segmentcentric strategies in service markets}

An example of this strategy is tiered services in a hair salon (eg men versus women). Since the same service firm provides service to multiple segments, cost estimation is less precise. In addition, pricing is based on the demand rather than actual costs. For example, women pay more for haircuts and dry cleaning than men do for similar services. Since the services and cost of services vary across providers, the marketing function cannot be accurately evaluated in pure financial terms of price premiums. Asset-based financial terms of number of customers and customer loyalty can, however, be accurately determined.

Segmentcentric strategies in product markets

An example of this strategy is segment-based products such as detergents. Since the same firm provides products to multiple segments, cost estimation is less precise. 
The cost of products and benefits to segments vary across firms, and the marketing function cannot be accurately evaluated in pure financial terms of price premiums. Here, again, asset-based financial terms of number of customers and customer loyalty can be accurately determined.

\section{Segmentcentric strategies in knowledge markets}

An example of this strategy is specialised software. In this situation, costs are typically dependent on volume, and pricing is difficult because demand projections need to be made. Prices are based on supply and demand, and perceived benefits typically prevail in pricing decisions. Since knowledge delivery varies across providers, the marketing function cannot be accurately evaluated in pure financial terms of price premiums. Once again, assetbased financial terms of number of customers and customer loyalty can be accurately determined.

\section{Customercentric strategies in service markets}

Examples of this strategy are janitorial services for businesses and construction services for customers. In these situations, thorough historical data costs are typically known and pricing is typically cost-plus and negotiated. The marketing function can be accurately evaluated in pure financial terms of price premiums, and in asset-based financial terms of number of customers and customer loyalty.
Customercentric strategies in product markets

Examples of this strategy are customerdriven or demand-driven manufacturing of products such as computers and even automobiles. In these situations, thorough historical data costs are typically known and pricing is typically cost-plus and/or negotiated. The marketing function can be accurately evaluated in pure financial terms of price premiums, and in asset-based financial terms of number of customers and customer loyalty.

\section{Customercentric strategies in knowledge markets}

Examples of this strategy are consulting and educational services. In these situations, pricing is established through negotiations, historical data and market situations. Since knowledge delivery varies across providers, the marketing function cannot be accurately evaluated in pure financial terms of price premiums. Asset-based financial terms of number of customers and customer loyalty can be accurately determined.

\section{RECOMMENDATIONS FOR MARKETING FIRMS}

Some approaches to improving financial measurement have already been discussed. In this section, additional perspectives on increasing the integration of financial measurement and marketing productivity are discussed.

The financial measures of market capitalisation are expected to become 
more important. Therefore, given product parity and near perfect information availability and matching, the quality of a firm's marketing strategy and execution will become important drivers of market capitalisation. Some of the more valuable companies in the world today, such as Microsoft and Coca Cola, possess few tangible assets as proportion of their market value. They have created financial wealth by virtue of acquiring and retaining a large base of valuable customers. In each case of the model framework, asset-based financial evaluation (eg number of customers and customer loyalty) was discussed. There is clearly a research need to better model and quantify the relationship. In the spirit of encouraging marketing academics to explore creative ways of looking at the new realities of the marketing function, several ideas to stimulate further exploration are presented below.

New ways of thinking about marketing The marketing function may need to balance its orientation. Traditionally, the marketing function has emphasised acquisition. The financial evaluation systems will lead to the marketing function emphasising customer retention as well. In the language of Srivastava, Shervani and Fahey, ${ }^{45}$ customers are the largest marketing assets of a firm.

New ways of organising the marketing function

If customers of firms are regarded as assets, firms will need to integrate the marketing function. Specifically, the sales-marketing-customer service separation needs to be disbanded. The marketing function needs to be organised on a network basis in which customer acquisition and retention will be twin goals to be implemented through insourcing and outsourcing. The availability of CRM systems will enable a larger number of marketing organisations to perform in a network manner.

New ways of thinking about markets and customers

The marketing function's conceptualisation about customers and markets will probably evolve in two ways. First, the marketing function will be concerned with smaller and smaller subgroups of customers, until a customercentric focus is achieved. Thus, markets will be seen to be composed of individual customers who have unique and differentiated needs. Secondly, customers will be regarded as assets of the organisation.

New ways of thinking about marketing information

The implications of this study/paper would clearly suggest that customerlevel information will be a key discriminator between very successful and less successful firms. Firms that have customer-level information will be able to change prices and offerings to maximise profits that firms with little information may not be able to match. For example, package 
delivery firms have found that for some customers, overnight delivery is less profitable than regular package delivery. This allows the package delivery firm to change the prices of overnight and standard deliveries based on the customer.

New ways of budgeting for marketing Marketing budgets are typically static, forecast-driven, and subject to the 'use it or lose it' rule. Firms will move toward budgets based on the size of the opportunity, the anticipated ROI, and the increase in shareholder value. This will require that the marketing budget for a brand be decoupled from the current revenue level of the brand, and be coupled instead to the opportunity for revenue and profit growth that the brand presents.

New ways of measuring performance and incentivising marketing employees

Marketing employees have traditionally been measured on sales and market share. Measures of profitability, shareholder value or market capitalisation are expected to begin to become more important. The major obstacles in the movement toward financial measures-based incentives for the marketing function are two-fold. First, there is an absence of information systems to collect data on the financial impact of the marketing function. Secondly, there is a need for a system that can isolate the effect of the marketing function from the role of financial markets on a firm's market capitalisation.

\section{CONCLUSION}

Based on the confluence of marketing productivity concerns and new markets and marketing, this paper suggests that marketing will gradually move toward better financial evaluation measures. Markets were conceptualised in terms of service, product and knowledge, and marketing practices in terms of product/brandcentric, segmentcentric and customercentric. In each case, the financial evaluation measures that can be accurately collected were then examined. With an increase in ability to determine the profitability of specific marketing practices, marketers can create better programmes.

\section{REFERENCES}

1 Schultz, D. E. and Gronstedt, A. (1997) 'Making marcom an investment', Marketing Management, Fall, pp. 41-49.

2 Reinartz, W. J. and Kumar, V. (2000) 'On the profitability of long-life customers in a non-contractual setting: An empirical investigation and implications for marketing', Journal of Marketing, Vol. 64, October. pp. 17-35.

3 Webster, F. E., Jr. (1980) 'Top management views of the marketing function', Marketing Science Institute, Cambridge, MA, p. 8.

4 Webster, F. E., Jr. (1992) 'The changing role of marketing in the corporation', Journal of Marketing, Vol. 56, October, pp. 1-17.

5 Srivastava, R. K., Shervani, T. A. and Fahey, L. (1998) 'Market-based assets and shareholder value: A framework 
for analysis', Journal of Marketing, Vol. 62, January, pp. 2-18.

6 Foster, G. and Gupta, M. (1994) 'Marketing, cost management and management accounting', Journal of Management Accounting Research, Vol. 6, pp. $43-77$.

7 Blattberg, R. C. and Deighton, J. (1996) 'Manage marketing by the customer equity test', Harvard Business Review, Vol. 96 (July-August), pp. 136-44.

8 Foster and Gupta (1994) op. cit.

9 Zeithaml, V. A. (2000) 'Service quality, profitability, and the economic worth of customers: What we know and what we need to learn', Journal of the Academy of Marketing Science, Vol. 28, No. 1, pp. 67-85.

10 Keiningham, T. L., Goddard, M. K. M., Vavra, T. G. and Iaci, A. J. (1999) 'Customer delight and the bottom line', Marketing Management, Fall, pp. 57-63.

11 Reinartz and Kumar (2000) op. cit.

12 Moorman, C., Zaltman, G. and Deshpande, R. (1992) 'Relationships between producers and users of market research: The dynamics of trust within and between organizations', Journal of Marketing Research, Vol. 29, August, pp. 314-328.

13 Grayson, K. and Ambler, T. (1999) 'The dark side of long-term relationships in marketing services', Journal of Marketing Research, Vol. 36, February, pp. 132-141.

14 Bucklin, L. P. (1978) 'Productivity in marketing', American Marketing Association, Chicago.

15 Donthu, N. and Yoo, B. (1998) 'Retail productivity assessment using data en- velopment analysis', Journal of Retailing, Vol. 74, Spring, pp. 74-92.

16 Ingene, C. A. (1982) 'Labor productivity in retailing, Journal of Marketing, Vol. 46, Fall, pp. 75-90.

17 Ingene, C. A. (1984) 'Productivity and functional shifting in spatial retailing: Private and social perspectives', Journal of Retailing, Vol. 60, Fall, pp. 15-36.

18 Ratchford, B. T. and Brown, J. R. (1985) 'A study of productivity changes in food retailing', Marketing Science, Vol. 4, Fall. pp. 292-311.

19 Ratchford, B. T. and Stoops, G. T. (1988) 'A model and measurement approach for studying retail productivity', Journal of Retailing, Vol. 64, Fall. pp. 241-263.

20 Kamakura, W. A., Lenartowicz, T. and Ratchford, B. T. (1996) 'Productivity assessment of multiple retail outlets', Journal of Retailing, Vol. 74, Winter, pp. 333-352.

21 Ibid.

22 Donthu and Yoo (1998) op. cit.

23 Kamakura, Lenartowicz and Ratchford (1996) op. cit.

24 Donthu and Yoo (1998) op. cit.

25 Ibid.

26 Ratchford and Stoops (1998) op. cit.

27 Chebat, J-C., Filiatrault, P., Katz, A. and Tal, S. (1994) 'Strategic auditing of human and financial resource allocation in marketing: An empirical study using data envelopment analysis', Journal of Business Research, Vol. 31. pp. 197208.

28 Donthu and Yoo (1998) op. cit.

29 Kamakura, Lenartowicz and Ratchford (1996) op. cit.

30 Donthu and Yoo (1998) op. cit. 
31 For example, Levy, M. and Weitz, B. A. (2000) 'Retailing management', fourth edition, Irwin, New York.

32 Simon, C. J. and Sullivan, M. W. (1993) 'The measurement and determination of brand equity: A financial approach', Marketing Science, Vol. 12, No. 1, pp. 28-52.

33 Foster and Gupta (1994) op. cit.

34 Ittner, C. D. and Lacker, D. F. (1998) 'Innovation in performance measurement: Trends and research implications', Journal of Management Accounting Research, Vol. 10, pp. 205-37.

35 Srivastava, Shervani and Fahey (1998) op. cit.

36 Day, G. S. and Montgomery, D. B. (1999) 'Charting new directions for marketing', Journal of Marketing, Vol. 63, No. 3, pp. 3-13.

37 Sheth, J. N., Sisodia, R. and Sharma, A. (2000) 'The antecedents and consequences of customer-centric marketing', Journal of the Academy of Marketing
Science, Vol. 28, No. 1, Winter, pp. 55-66.

38 Ibid.

39 Kotler, P. (1967) 'Marketing management: Analysis, planning, and control', Prentice-Hall, Englewood Cliffs, NJ.

40 Kohli, A. K. and Jaworski, B. J. (1990) 'Market orientation: The construct, research propositions, and managerial implications', Journal of Marketing, Vol. 54, No. 2, April, pp. 1-13.

41 Narver, J. C. and Slater, S. F. (1990) 'The effect of market orientation on business profitability', Journal of Marketing, Vol. 54, No. 4, October, pp. 2033.

42 Sheth, Sisodia and Sharma (2000) op. cit.

43 Srivastava, Shervani and Fahey (1998) op. cit.

44 Sheth, Sisodia and Sharma (2000) op. cit.

45 Srivastava, Shervani and Fahey (2000) op. cit. 